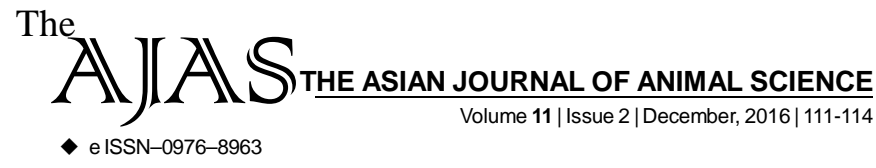

DOI : 10.15740/HAS/TAJAS/11.2/111-114
Visit us | www.researchjournal.co.in

RESEARCH ARTICLE........

\title{
Effect of supplementation of bypass fat on biochemical profile in dairy cows
}

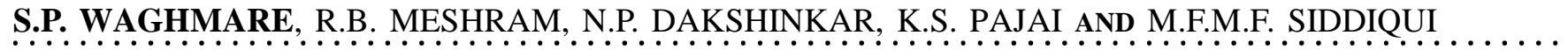

Author for Corresponding -

\section{S.P. WAGHMARE}

Post Graduate Institute of Veterinary and Animal Sciences (P.G.I.V.A.S.), AKOLA (M.S.) INDIA Email: wps25@rediffmail.com

See end of the article for Coopted authors'

\begin{abstract}
The present investigation was undertaken with the objective to evaluate the effect of supplementation of bypass fat on biochemical profile in dairy cows. Total 12 healthy advanced pregnant cows (10 days before expected parturition) were selected and divided randomly into two equal groups. One group (Group I) of 6 cows was kept without supplementation of bypass fat and given only basal diet as a control group. The second group (Group II) of 6 cows was supplemented with rumen bypass fat (Extra Energy Plus) @ $100 \mathrm{~g}$ per animal per day along with basal diet for the period of 4 weeks after parturition. Blood biochemical parameters such as plasma glucose, serum cholesterol, serum triglyceride, serum calcium and serum phosphorus were estimated in all the animals before supplementation (' 0 ' day) and on $7^{\text {th }}, 14^{\text {th }}, 21^{\text {st }}$ and $30^{\text {th }}$ day after supplementation. The supplementation of rumen bypass fat (Group II), maintained the levels of plasma glucose, serum cholesterol, serum triglyceride, serum calcium and serum phosphorus within normal range, whereas, in non supplemented group (Group I), plasma glucose and serum phosphorus levels decreased and serum triglyceride level increased significantly. The present study concluded that supplementation of rumen bypass fat proved beneficial in fulfilling the energy demand for production and prevented the cows entering into negative energy balance during early midlactation.
\end{abstract}

KEY WORDS....... Advanced pregnant cows, Lactation, Bypass fat, Biochemical parameters

HOW TO CITE THIS ARTICLE - Waghmare, S.P., Meshram, R.B., Dakshinkar, N.P., Pajai, K.S. and Siddiqui, M.F.M.F. (2016). Effect of supplementation of bypass fat on biochemical profile in dairy cows. Asian J. Animal Sci., 11(2): 111-114. DOI : 10.15740/HAS/TAJAS/11.2/111-114.

ARTICLE CHRONICLE - Received : 20.09.2016; Revised : 17.10.2016; Accepted : 01.11.2016 